$P>0 \cdot 1)$ pressure though both of these preparations were associated with greater rises of diastolic pressure than the other two combinations. From these results there is no evidence to suggest that an increase in progestogenic potency is associated with a larger change in blood pressure.

\section{Discussion}

The results of this further analysis have confirmed our previous report (Weir et al., 1971 a) of a rise in systolic blood pressure in women taking oestrogen-progestogen oral contraceptives. Rises in diastolic pressure became statistically significant two years after starting treatment. Both rises of pressure are generally readily reversible (fig. 4). These findings are in accord with other series (Carmichael et al., 1970; Spellacy and Birk, 1972; Clezy et al., 1972) but the rises in blood pressure are not as great as those reported under less standardized conditions (Saruta et al., 1970; Crane et al., 1971).

Two studies have suggested that oral contraceptives are more likely to induce changes in blood pressure in women with a history of pre-eclampsia (Spellacy and Birk, 1972; Clezy et al., 1972), though Smith (1972) did not confirm these findings. The data in the present prospective survey are still insufficient for us to comment about this, but elsewhere we have reported on 23 isolated cases of marked rises in blood pressure associated with taking oral contraceptives where there was no evidence that previous pre-eclampsia was a contributing factor (Weir et al., 1974). Though a role for sodium and water retention in producing the initial rise in blood pressure has not so far been excluded, we have found no relation between the changes in blood pressure and changes in weight $(r=0.18 ; P>0.1)$ or in sodium, potassium, or water balance (Weir et al., 1971 b).

No increase in blood pressure has been found in women taking progestogen only (MacKay et al., 1971; Spellacy and Birk, 1972), and the present study has shown that the changes in blood pressure are not related to the progestogenic potency of the combined preparations used. A rise in blood pressure during oestrogen administration, however, has been reported (Lim et al., 1970; Crane et al., 1971; Spellacy and Birk, 1972), and possibly the increase in blood volume, cardiac output, and blood pressure in women taking combined oral contraceptives
(Walters and Lim, 1970) may be induced by the oestrogen component. To date, the effect of preparations with different oestrogenic potencies has not been adequately studied.

The increases in blood pressure in this prospective survey have not so far been accompanied by clinical complications and would not generally be regarded as clinically important. Nevertheless, mortality and morbidity statistics, mostly obtained for men (Pickering, 1968; Kannel et al., 1971), suggest that a relatively small increase of blood pressure within the range found in this study carries a distinct risk. Possibly, therefore, prolonged administration of oestrogen-progestogen oral contraceptives may lead to levels of blood pressure which may increase morbidity and affect life expectancy.

This study was supported in part by grants from the Council for the Investigation of Fertility Control and the Family Planning Association. We thank Mrs. Elizabeth Cree for her enthusiastic secretarial assistance, and Dr. A. F. Lever for his helpful criticism and advice.

\section{References}

Carmichael, S. M., Taylor, M. M., and Ayers, C. R. (1970). Obstetrics and Gynaecology, 35, 371.

Clezy, T. M., Foy, B. N., Hodge, R. L., and Lumbers, E. R. (1972). British Heart fournal, 34, 1238.

Crane, M. G., Harris, J. J., and Winsor, W. (1971). Annals of Internal Medicine, 74, 13.

Kannel, W. B., Gordon, T., and Schwartz, M. J. (1971). American fournal of Cardiology, 27, 335.

Lim, Y. L., Lumbers, E. R., Walters, W. A. W., and Whelan, R. F. (1970) Fournal of Obstetrics and Gynaecology of the British Commonwealth, 77, 349.

MacKay, E. V., Khoo, S. H., and Adam, R. R. (1971). Australian and New Zealand Fournal of Obstetrics and Gynaecology, $11,148$.

Pickering, G. (1968). High Blood Pressure, 2nd edn., p. 367. London, Churchill.

Saruta, T., Saade, G. A., and Kaplan, N. M. (1970). Archives of Internal Medicine, 126, 621 .

Smith, R. W. (1972). Amercian fournal of Obstetrics and Gynecology, 113, 482. Spellacy, W. N., and Birk, S. A. (1972). American fournal of Obstetrics and Gynecology, 112, 912 .

Gynecology, 112, 912.
Walters, W. A. W., and Lim, Y. L. (1970). Fournal of Obstetrics and Gynaecology of the British Commonwealth, 77, 1007.

Weir, R. J., et al. (1971 a). Lancet, 1, 467.

Weir, R. J., et al. (1971 b). Excerpta Medica International Congress Series, No. $219,929$.

Weir, R. J., Tree, M., and McElwee, G. (1974). Proceedings of 3rd International Congress of Endocrinology, Washington. Excerpta Medica International Congress Series No. 273

\title{
Interaction between Doxycycline and Barbiturates
}

\author{
P. J. NEUVONEN, O. PENTTILÄ
}

British Medical fournal, 1974, 1, 535-536

\section{Summary}

In a cross-over study of five hospitalized patients the half life of doxycycline was significantly shortened after 10 days' treatment with phenobarbitone. In five patients on continuous barbiturate therapy the half life of doxycycline was even shorter. Barbiturates or other agents inducing drug metabolism should be used cautiously in combination with doxycycline, since this might result in therapeutically inadequate serum concentrations of the antibiotic.

\footnotetext{
Department of Clinical Pharmacology, University of Helsinki, SF-00290 Helsinki 29

P. J. NEUVONEN, M.D., Assistant Professor

Department of Medicine, Maria Hospital, SF-00180 Helsinki 18 O. PENTTILÄ, M.D., Consultant Physician
}

\section{Introduction}

For treatment with bacteriostatic agents to be successful the serum antibiotic level must not fall below the minimum inhibitory concentration. Certain drugs interfere with the gastrointestinal absorption of tetracyclines (Waisbren and Hueckel, 1950; Neuvonen et al., 1970). Hepatic metabolism seems to be important in the elimination of doxycycline and the drug does not accumulate significantly in renal insufficiency (Klinger et al., 1970). Barbiturates and many other commonly used preparations stimulate metabolism of drugs through inducing hepatic microsomal enzyme activity (Breckenridge and Orme, 1971; Remmer, 1972; Prescott, 1973). The present study aimed to discover whether barbiturates modify the half life of doxycycline in man.

\section{Patients and Methods}

Ten chronically ill patients volunteered as subjects for the study. Their usual daily medication of digitalis and diuretics and, in 
TABLE I-Details of Patients in Group B

\begin{tabular}{|c|c|c|c|c|c|c|c|}
\hline Case No. & Sex & Age & $\underset{(\mathbf{k g})}{\text { Weight }}$ & Inducing Agent(s) & $\begin{array}{c}\text { Daily Dose } \\
\text { (mg) }\end{array}$ & Duration of Therapy & $\begin{array}{l}\text { Half Life of Doxycycline } \\
(\mathrm{hr})\end{array}$ \\
\hline $\begin{array}{l}1 \\
2 \\
3 \\
4 \\
5\end{array}$ & $\begin{array}{l}\text { M. } \\
\text { M. } \\
\text { F. } \\
\text { M. }\end{array}$ & $\begin{array}{l}60 \\
35 \\
73 \\
65 \\
78\end{array}$ & $\begin{array}{l}65 \\
85 \\
60 \\
60 \\
60\end{array}$ & $\begin{array}{l}\text { Phenobarbitone } \\
\text { Diphenylhydantoin } \\
\text { Carbamazepine } \\
\text { Pentobarbitone } \\
\text { Amylobarbitone } \\
\text { Phenobarbitone } \\
\text { Pentobarbitone }\end{array}$ & $\begin{array}{l}100 \\
400 \\
300 \\
150 \\
200 \\
100 \\
100\end{array}$ & $\begin{array}{c}5-7 \text { years } \\
6 \text { weeks } \\
30 \text { years } \\
12 \text { weeks } \\
5 \text { weeks }\end{array}$ & $\begin{array}{r}5 \cdot 6 \\
5 \cdot 7 \\
7 \cdot 9 \\
8 \cdot 1 \\
11 \cdot 0\end{array}$ \\
\hline & & & & & & Mean \pm S.E. & $7 \cdot 7 \pm 1 \cdot 0^{*}$ \\
\hline
\end{tabular}

* Significantly shorter than during the control period in table II $(\mathrm{P}<0.005)$.

five cases, of barbiturates was continued during the experimental period but no other drugs were being taken. The patients were divided into two groups of five. Group A consisted of three women and two men whose ages ranged from 48 to 82 years and their weight from 50 to $60 \mathrm{~kg}$. They were each given a single dose of doxycycline hydrochloride $100 \mathrm{mg}$ intravenously, and its half life was determined from blood samples taken $1,3,5,8$, 12,24 , and 36 hours later. Thereafter phenobarbitone sodium $50 \mathrm{mg}$ was given thrice daily for 10 days, when the half life of a single dose of doxycycline was again determined as described above. The five patients in group B, of similar ages and weights to those in group $\mathrm{A}$, had been taking barbiturate drugs as a hypnotic or antiepileptic for periods varying from several weeks to several years (table I). The half life of a single dose of doxycycline in these patients was determined as described above without discontinuing their barbiturates.

The serum concentration of doxycycline in each blood sample was measured both microbiologically by the agar-plate method of Bennett et al. (1966), on Bacto Penassay Seed Agar (Difco) with Bacillus Cereus A.T.C.C. 9,634 as test organism, and fluorometrically according to Kohn (1961). The fluorometric values were definitely higher than the microbiological, but the half lives of doxycycline did not differ. Means with standard errors (S.E.) were calculated and Student's $t$ test both for paired and unpaired values was used for statistical evaluation.

TABLE II-Effect of 10 Days' Treatment with Phenobarbitone on Half Life of Doxycycline

\begin{tabular}{|c|c|c|}
\hline Case No. & $\begin{array}{l}\text { Half Life Before } \\
\text { Phenobarbitone } \\
\text { (hr) }\end{array}$ & $\begin{array}{l}\text { Half Life After } \\
\text { Phenobarbitone } \\
\text { (hr) }\end{array}$ \\
\hline $\begin{array}{l}1 \\
2 \\
3 \\
4 \\
5\end{array}$ & $\begin{array}{l}10.4 \\
14.9 \\
16.1 \\
17.5 \\
17.8\end{array}$ & $\begin{array}{r}7.2 \\
12.0 \\
10.6 \\
11.7 \\
13.8\end{array}$ \\
\hline Mean \pm S.E. & $15 \cdot 3 \pm 1 \cdot 3$ & $11 \cdot 1 \pm 1 \cdot 1^{*}$ \\
\hline
\end{tabular}

* Significantly shorter than during control period $(P<0.005)$.

\section{Results}

The half life of doxycycline was $15 \cdot 3 \pm 1.3$ hours in the patients in group A during the control period. After 10 days' treatment with phenobarbitone the half life of doxycycline was $11 \cdot 1 \pm 1 \cdot 1$ hours, significantly shorter $(P<0.005)$ (table II). In patients in group $B$ on long-term barbiturate therapy the half life of doxy- cycline was $7 \cdot 7 \pm 1 \cdot 0$ hours (table $I$ ), significantly shorter than in patients in group $A$ during the control period $(P<0.005)$.

\section{Discussion}

The introduction of phenobarbitone to the drug regimen of patients in group A shortened the half life of doxycycline in each case, and in all the patients on long-term barbiturate therapy the half life was even shorter. Therefore it is reasonable to assume that the degree of induction of doxycycline metabolism correlates with the duration of barbiturate therapy and also depends on the type and dose of barbiturate (Breckenridge et al., 1973). The half life of doxycycline did not return to normal for two weeks after the cessation of barbiturate therapy.

The clinical significance of enzyme induction is not limited to barbiturates, and the range of inducing agents is much wider (Remmer, 1972). In a preliminary study we found the half life of doxycycline to be shortened in patients taking diphenylhydantoin and certain other drugs known to be potent enzyme inducers. Perhaps other tetracycline derivatives are also affected, but obviously the clinical significance of enzyme induction is more important in relation to the long-acting lipophilic tetracycline derivatives in which the maintenance of adequate serum concentrations is dependent on the rate of metabolism and not on renal excretion. If possible, therefore, doxycycline should not be given in combination with barbiturates, and serum doxycycline levels should always be measured when this antibiotic is given with drugs known to be enzyme inducers.

We thank the patients who volunteered to take part in this trial. We are also grateful to Dr. O.-V. Renkonen, Mrs. Elina Selin, and Miss Ulla Wessman for the determinations of doxycycline. We are indebted to Pfizer Inc. and to the National Research Council for Medical Sciences, Finland.

\section{References}

Bennett, J. V., Brodie, J. L., Benner, E. J., and Kirby, W. M. M. (1966). Applied Microbiology, 14, 170.

Breckenridge, A., and Orme, M. (1971). Annals of the New York Academy of Sciences, 179, 421.

Breckenridge, A., Orme, M. L'E., Davies, L., Thorgeirsson, S. S., and Davies, D. S. (1973). Clinical Pharmacology and Therapeutics, 14, 514

Klinger, W., Bayerl, P., and Edel, H. (1970). Progress in Antimicrobial and Anticancer Chemotherapy: Proceedings of the Sixth International Congress of Chemotherapy, 1,605 .

Kohn, K. W. (1961). Analytical Chemistry, 33, 862

Neuvonen, P. J., Gothoni, G., Hackman, R., and af Björksten, K. (1970). British Medical fournal, 4, 532 .

Prescott, L. F. (1973). Drugs, 5, 161.

Remmer, H. (1972). European fournal of Clinical Pharmacology, 5, 116.

Waisbren, B. A., and Hueckel, J. S. (1950). Proceedings of the Society for Experimental Biology and Medicine, 73, 73. 